\title{
Quality of life in sickle cell disease: assessments by the 36-item Short Form Health Survey Questionnaire and Beck Depression Inventory
}

\author{
Maria Lucia Ivo ${ }^{1}$ \\ Marcos Antonio Ferreira Júnior ${ }^{2}$ \\ Universidade Federal do Mato Grosso do Sul \\ - UFMS, Campo Grande, MS, Brazil \\ ${ }^{2}$ Universidade Federal do Rio Grande do \\ Norte - UFRN, Natal, RN, Brazil
}

Conflict-of-interest disclosure:

The authors declare no competing financial interest

Submitted: 11/12/2012

Accepted: 11/13/2012

Corresponding author:

Maria Lucia Ivo

Universidade Federal de Mato Grosso do Sul - UFMS

Av. Senador Filinto Müller, s/nº, Bloco 9, Bairro Vila Ipiranga

79080-190 Campo Grande, MS, Brazil

ivoms@terra.com.br

www.rbhh.org or www.scielo.br/rbhh
Quality of life is characterized by a remarkably interdisciplinary construct involving different fields of knowledge. In Brazil, a country of striking regional and cultural differences, the broad and systematic use of generic questionnaires for quality of life, such as the 36-item Short Form Health Survey Questionnaire (SF-36) ${ }^{(1)}$ and the Beck Depression Inventory (BDI), can help gather evidence about psychometric qualities. A noteworthy aspect is the standardized questions, used to collect experience of people facing diseases and to assess the impact of treatment on their well-being, thus representing an efficient means for measuring the health status. In this context, the health-related quality of life (HR-QoL) refers to the person's functionality in daily tasks, the effects caused by diseases, treatment and damage to their quality of life, and to the well-being perceived by them ${ }^{(2)}$.

The SF-36, used to assess HR-QoL, is translated into several languages and validated for different cultures by the International Quality of Life Assessment (IQoLA) Project. Translation into Portuguese was adapted to the socioeconomic and cultural conditions and validated for the first time in 50 patients with rheumatoid arthritis (RA). It was shown that three dimensions of the questionnaire, i.e. functional capacity, physical aspects/limitations and pain, presented an average lower than the other components. The Portuguese version was also proved to be reproducible and valid for Brazilian patients with RA and other diseases ${ }^{(3)}$.

The BDI, instrument used to assess the severity of depression, was validated for the Portuguese language ${ }^{(4)}$. The psychometric properties were analyzed and the profile detected by means of three samples: college students, patients with panic disorder and patients with depression. The Portuguese version was shown to be reproducible and valid for discriminating depressive symptoms and assessing aspects of depression.

The relevant results of the scientific study entitled "Quality of life of individuals with sickle cell disease followed at referral centers in Alagoas, Brazil," published in this issue of the Revista Brasileira de Hematologia e Hemoterapia, proved that these two tools were suitable to measure the quality of life (SF-36) and symptoms of depression (IBD) in 40 people with sickle cell disease $(\mathrm{SCD})^{(5)}$. These instruments found overall impairment in HR-QoL with greater intensity in under 15-year-old adolescents and adults, the latter presenting with pain and mood disorder.

In summary, the analysis of the use of SF-36 shows that Brazilian adolescents with SCD have similarities with teens in other parts of the world, especially Saudi Arabia ${ }^{(6)}$, with losses in HR-QoL, in terms of general physical health (body pains), when compared with their healthy peers. As SCD is a severe disease it has an impact on the social and emotional conditions of sufferers with these aspects often being underestimated by healthcare professionals ${ }^{(7)}$.

\section{References}

1. Seidl EM, Zanon CM. Qualidade de vida e saúde: aspectos conceituais e metodológicos. Cad Saúde Pública. 2004;20(2):580-8.

2. Lima MJ, Portela MC. Elaboração e avaliação da confiabilidade de um instrumento para medição da qualidade de vida relacionada à saúde de idosos independentes. Cad Saúde Pública. 2010;26(8):1651-62.

3. Ciconelli RM, Ferraz MB, Santos W, Meinão I, Quaresma MR. Tradução para a língua portuguesa e validação do questionário genérico de avaliação de qualidade de vida SF-36 (Brasil SF-36). Rev Bras Reumatol. 1999;29(3):143-50.

4. Gorestein C, Andrade L. Beck Depression Inventory: psychometric properties of the Portuguese version Rev Psiq Clin. 1998;25(5):245-50.

5. Vilela RQ, Cavalcante JC, Cavalcante BF, Araújo DL, Lôbo MM, Nunes FA. Quality of life of individuals with sickle cell disease followed at referral centers in Alagoas, Brazil. Rev Bras Hematol Hemoter. 34(6):442-6

6. Amr MA, Amin TT, Al-Omair OA. Health related quality of life among adolescents with sickle cell disease in Saudi Arabia. Pan Afr Med J. 2011;8:10.

7. Asnani MR, Reid ME, Ali SB, Lipps G, Williams-Green P. Quality of life in patients with sickle cell disease in Jamaica: rural-urban differences. Rural Remote Health. 2008;8(2):890. 